\title{
Tıp fakültesi öğrencileri arasında huzursuz bacak sendromu sıklığı, depresyon, anksiyete ve uyku kalitesi arasındaki ilişki
}

\author{
Muzaffer SARIAYDIN \\ Ersin GÜNAY ${ }^{1}$ \\ Mehmet ÜNLÜ 1
}

\footnotetext{
1 Afyon Kocatepe Üniversitesi Tıp Fakültesi, Göğüs Hastalıkları Anabilim Dalı, Afyonkarahisar, Türkiye

${ }^{1}$ Department of Chest Diseases, Faculty of Medicine, Afyon Kocatepe University, Afyonkarahisar, Turkey
}

\section{ÖZET}

Tıp fakültesi öğrencileri arasında huzursuz bacak sendromu sıkığı, depresyon, anksiyete ve uyku kalitesi arasındaki ilişki

Giriş: Çalışmamızda tıp fakültesi öğrencileri arasında huzursuz bacak sendromu (HBS) sıklı̆̆ını, depresyon, anksiyete ve uyku kalitesi arasındaki ilişkiyi saptamayı amaçladık.

Materyal ve Metod: Çalışma tıp fakültesi öğrencilerine anket uygulanarak yapıldı. Ankette, demografik özellikleri belirlemeye yönelik olan soruların ardından HBS tanı kriterlerini içeren sorular soruldu. HBS tanısı alan katılımcılara HBS şiddeti değerlendirme ölçeği uygulandı. Bütün katılımcılara ayrıca, pittsburgh uyku kalitesi indeksi (PUKi), beck depresyon ölçeği (BDÖ) ve beck anksiyete ölçeği (BAÖ) uygulandı. Tüm sonuçlar HBS var olan ve olmayan olgular arasında karşılaştırıldı.

Bulgular: Çalışmaya \%55.2 (n= 222)'si kız olmak üzere 402 tıp fakültesi öğrencisi katıldı. HBS tanı kriterlerini karşılayanların oranı $\% 16.9$ ( $n=68)^{\prime}$ du. HBS'nin kız öğrencilerdeki oranı \% $18(n=40)$, erkeklerde \% $15.6(n=28)$ olarak bulundu. Kötü uyku kalitesi olan 169 ögrrencinin içinde HBS tanısı olan 36 (\%21.3), iyi uyku kalitesi olan 233 öğrencinin de HBS olan 32 (\% 13.7) öğrenci vardı ( $p=$ 0.004). HBS tanısı alan olgularda HBS şiddet değerlendirme ölçeği ile BDÖ ve BAÖ puanları karşılaştırıldığında şiddet ile depresyon ve anksiyete durumlarında pozitif korelasyon olduğu saptandı (sırasıly; $p=0.002, r=0.372$ ve $p<0.001, r=0.506$ ).

Sonuç: Çalışmamızın sonuçlarında tıp fakültesi öğrencilerinde HBS sıklığı literatürde belirtilen oranlardan yüksek olarak tespit edildi. HBS tanıı konulan olguların kötü uyku kalitesine sahip oldukları görüldü. Ayrıca, HBS bazı psikolojik duygu durum bozuklukları ile sıklıkla birlikte olabileceği gösterildi.

Anahtar kelimeler: Huzursuz bacak sendromu; uyku kalitesi; anksiyete; depresyon

\section{SUMMARY}

Frequency of restless legs syndrome and relationship between depression, anxiety and sleep quality among medical school students Introduction: We aimed to investigate the relationship between frequency of restless legs syndrome (RLS), depression, anxiety and sleep quality among medical school students.

Materials and Methods: We applied a questionnaire to medical school students. This questionnaire includes some questions about demographic features of participants, questions related with RLS diagnosis, the pittsburgh sleep quality index (PSQI), beck-

\section{Yazışma Adresi (Address for Correspondence)}

Dr. Muzaffer SARIAYDIN

Afyon Kocatepe Üniversitesi Tıp Fakültesi, Göğüs Hastalıkları Anabilim Dalı, AFYONKARAHISAR - TÜRKIYE

e-mail: msariaydin01@gmail.com 
depression-scale (BDS), beck-anxiety scale (BAS) to all subjects. Participants diagnosed with RLS asked to response some additional questions related with RLS severity rating scale. All results compared between RLS diagnosed and healthy subjects.

Results: A total of 402 medical school students, of whom $55.2 \%(n=22)$ were female, were participated into this study. The ratio of subjects diagnosed as RLS was $16.9 \%(n=68)$. The ratio of RLS diagnosed participants in female students was $18.0 \%(n=40)$ and in male students was $15.6 \%$ ( $n=28)$. Of 169 participants who got a poor sleep quality, 36 subjects (21.3\%) was diagnosed as RLS. On the other hand, of 233 participants who got a good sleep quality, 32 subjects (13.7\%) was diagnosed as RLS ( $p=0.004)$. Score for the RLS severity ranging scale for participants who were diagnosed as RLS was positively correlated with both BDS and BAS sCores ( $p=0.002, r=0.372$ ve $p<0.001, r=0.506$, respectively).

Conclusion: In this study, the rate of RLS in medical school students were higher than the rate presented in the literature. Additionaly, participants who were diagnosed as RLS in our study had worse sleep quality than healthy subjects. Moreover, RLS may be associated with some psychological mood disorders.

Key words: Restless legs syndrome; sleep quality; anxiety; depression

\section{Giriş}

Huzursuz bacak sendromu (HBS), Willis-Ekbom hastalığı olarak da bilinen, bacakları hareket ettirme isteği veya ihtiyacıyla ortaya çıkan, anormal duyularla karakterize, kronik, ilerleyici bir hareket bozukluğu hastalığıdır. HBS terimi ilk olarak 1945'te isveçli nörolog Dr. Karl A. Ekbom tarafından, ekstremitelerde özellikle hastalarda istirahat sırasında görülen, duyusal semptom ve motor rahatsızlığı ifade etmek için kullanılmıştır (1).

Hastalığın genel popülasyondaki sıklığı \%1-15 arasında bildirilmektedir (2). Toplumda bu kadar yaygın olmasına rağmen ekstermitelerde ağrı, hareket bozukluğu ve uyku problemi gibi benzer klinik özellikler gösteren diğer klinik durumlarla karışabilmektedir. HBS'li hastalar, bu rahatsız edici semptomları tanımlamakta güçlük yaşamaktadırlar. Bu rahatsızlık hissi geceleri şiddetlenmekte ve genellikle hastaları uykudan uyandırmakta, böylece de kronik uyku bozukluğu ve emosyonel strese neden olmaktadır. HBS uyku bozukluklarının sık bir nedeni olarak normal yaşam fonksiyonlarını bozabilen klinik bir durumdur $(1,2)$.

Çalışmamızda tıp fakültesi öğrencileri arasında HBS sıklığını, depresyon, anksiyete ve uyku kalitesi arasındaki ilişkiyi saptamayı amaçladık.

\section{MATERYAL ve METOD}

Tıp fakültesi öğrencilerine 01-15 Ocak 2016 tarihleri arasında çalışma ile ilgili sözel bilgilendirme yapıldıktan sonra çalışmaya katılmayı kabul eden öğrencilerden bilgilendirilmiş onamları alındı. Çalışma için tarafımızca hazırlanmış anket soruları çalışmaya katılmayı kabul etmiş olan öğrencilere dağıtılıp soruları kendilerinin cevaplaması istendi. Ankette demografik özellikleri belirlemeye yönelik olan soruların ardından, anemi dahil herhangi bir kronik hastalığı ve düzenli ilaç kulanım öyküsü olup olmadığı soruldu. Ek hastalığı ve anemisi olan olgular çalışma dışı bırakıldı. Tüm katılımcılara Uluslararası HBS Çalışma Grubu (IRLSSG) tarafından belirlenen ve en son 2014 yılında güncellenen 5 soruluk HBS tanı kriterleri anketi ve tüm sorulara evet cevabı vererek HBS tanısı alan katılımcılara IRLSSG tarafından belirlenen HBS şiddet değerlendirme ölçeği (HBSŞDÖ) uygulandı (2). Şiddet değerlendirme ölçeği toplam 10 sorudan oluşmakta ve ölçeğin puanı 0-40 arasında değişmektedir. Sonuçlara göre; 1-10 puan arası hafif, 11-20 puan arası orta, 21-30 puan arası şiddetli, 31-40 puan arası ise çok şiddetli hastalık varlığını göstermektedir.

Çalışmaya dahil edilen tüm katılımcılara uyku kalitesini belirlemek amacıyla pittsburgh uyku kalitesi indeksi (PUKi) ve depresyon, anksiyete ilişkisini belirlemek için Beck depreyon ve anksiyete ölçeği kullanıldı. HBS tanısı alan ve almayan olgular PUKi, Beck depresyon ve anksiyete ölçeği sonuçlarıyla karşılaştırıldı.

Uyku kalitesinin değerlendirilmesinde kullanılan PUKi, Türk toplumunda geçerlilik ve güvenilirliği gösterilmiş bir ölçektir (3). Uyku süresi, uyku dağılımı, uyku latansı, günlük işlerde aksama, uyku verimliliği, uyku kalitesi ve uyku ilacı kullanımı olmak üzere 7 öğenin değerlendirildiği ölçekte toplam puanlama 0-21 arasında değişmektedir. Toplam 5'ten fazla puan uyku kalitesinin kötü olduğunu göstermektedir (3).

Beck depresyon ölçeği (BDÖ) sağlıklı ve psikiyatrik hasta gruplarına uygulanan, kendini değerlendirme ölçeğidir. Toplam 21 soru içeren bu ölçekte, her soru 0-3 arasında puanlanır. Toplam puan 0-63 arasında 
değişmektedir. Toplam puanın yüksek olması depresyon şiddetinin yüksekliğini gösterir. Depresyonun derecelendirilmesi soncunda; 0-9 puan arası minimal depresif belirtiler, 10-16 puan arası hafif düzeyde depresif belirtiler, 17-29 puan arası orta düzeyde depresif belirtiler, 30-63 puan arası şiddetli düzeyde depresif belirtiler şeklinde değerlendirilmiştir. Dr. Aaron T. Beck tarafından geliştirilmiş ve Türk toplumu için uyarlama, geçerlilik ve güvenilirlik çalışmaları yapılmıştır (4-6).

Dr. Aaron T. Beck ve arkadaşları tarafından kişinin anksiyete durumunu değerlendirmesi için geliştirdiği diğer bir ölçek de beck anksiyete ölçeği (BAÖ)'dir (7). Toplam 21 sorudan oluşan ölçeğin her sorusu 0-3 arasında puan alır. Toplam puan 0-63 arasında değiş̧mektedir. Ölçekten alınan puanın yüksekliği, bireyin yaşadığı anksiyetenin şiddetini gösterir. Puanlamadan elde edilen sonuçlarda 0-7 puan arası minimal düzeyde anksiyete belirtisini, 8-15 puan arası hafif düzeyde anksiyete belirtilerini, 16-25 puan arası orta düzeyde anksiyete belirtilerini ve 26-63 puan arası şiddetli düzeyde anksiyete belirtilerini gösterir. Ülkemizde BAÖ için geçerlilik ve güvenirlik çalışması yapılmıştır (6).

\section{İstatistiksel Analiz}

Analiz için SPSS (SPSS version 16.0, SPSS Inc., Chicago, IL, USA) programı kullanıldı. Sayısal verilerin normal dağılımı Kolmogorov-Smirnov testi kullanılarak değerlendirildi. Sayısal verilerin analizi normal dağılım durumuna Student's t-test veya MannWhitney $U$ test kullanılarak karşılaştıııldı. Kategorik değişkenlerin analizinde Ki-kare testi kullanıldı. Korelasyon testi için Spearman korelasyon analizi kullanıldı. Anlamlı istatistik $\mathrm{p}$ değer olarak $<0.05$ kabul edildi.

\section{BULGULAR}

Çalışmaya $222(\% 55.2)$ kız ve $180(\% 44.8)$ erkek olmak üzere 402 tıp fakültesi öğrencisi katıldı. Katılanların \%15.3 (63 öğrenci)'ü birinci sınıf, \%28.1 (113 öğrenci)'i ikinci sınıf, \%20.9 (84 öğrenci)'u üçüncü sınıf, \%11.9 (48 öğrenci)'u dördüncü sınıf, \%17.4 (70 öğrenci)'ü beşinci sınıf ve \%6.0 (24 öğrenci)'sı altıncı sınıf öğrencisiydi. Yaş ortalaması 21.18 yıl (18-25)'dı. Kız öğrencilerde yaş ortalaması 21.04 (18-26), erkeklerde 21.36 (18-27)'ydı.

HBS tanı kriterlerini karşılayanların oranı \%16.91 $(n=$ 68) olarak saptandı. HBS'nin kadınlarda oranı \%18.01 $(n=40)$, erkeklerde \%15.6 ( $n=28)$ olarak bulundu.
HBS tanısı alan öğrencilerin cinsiyetleri benzerdi $(p=0.513)$. HBS olanların HBS şiddet ölçeğine göre ortalama puanı $15.73 \pm 7.32^{\prime} y d i$. HBS tanılı öğrencilerin \%23.3 ( $n=7)^{\prime}$ ü hafif, \%50 ( $\left.n=15\right)^{\prime}$ 'si orta, \%26.7 ( $\mathrm{n}=8)^{\prime}$ 'si ağır olarak değerlendirildi. Kız ve erkek öğrenciler arasında şiddet açısından farklılık saptanmadı ( $p=0.75)$. Preklinik $(1,2$ ve 3 . sınıf) öğrencilerde HBS tanı kriterini karşılayan öğrenci sayısı 26 (\%18.3), klinik (4, 5 ve 6. sınıf) öğrencilerde $42(\% 16.2)(p=0.865)$ olarak bulundu.

Sigara kullananların sayısı 71'ken (\%20.9), haftada en az bir gün olmak üzere alkol kullanan 17 olgu (\%4.2) vardı. HBS tanısı olan ve olmayan gruplar arasında sigara ve alkol kullanımı açısından anlamlı fark bulunmadı $(\mathrm{p}=0.587)$.

Uyku kalitesi sonuçları değerlendirildiğinde, çalışmaya dahil olan tüm olguların PUKi ölçeğinden aldıkları ortalama puan $4.4 \pm 2.44^{\prime}$ tür (0-12). Olguların 169 (\%42.03)'unun 5 puan üzeri alarak kötü uyku kalitesine sahip olduğu görüldü. İyi uyku kalitesi olan 233 olgunun 32 (\%13.73)'sinde HBS bulguları varken, 169 kötü uyku kalitesi olan olgunun 36 (\%21.3)'sında HBS bulgularının olduğu saptandı $(p=0.004)$ (Şekil 1).

Olguların BDÖ toplam puanı ortalama $10.37 \pm$ 6.40 'dı (0-54 puan). HBS bulguları var olan 68 olgunun BDÖ şiddetine göre 23 (\%33.82)'ünde minimal düzeyde depresif belirtiler, 21 (\%30.88)'inde orta düzeyde depresif belirtiler, $19(\% 27.94)^{\prime}$ unda orta düzeyde depresif belirtiler, 5 (\%7.35)'inde şiddetli düzeyde depresif belirtiler olduğu görüldü. HBS bulguları olmayan 334 olgunun BDÖ şiddetine göre 192 (\%57.48) minimal düzeyde depresif belirtiler, 75 (\%22.45) orta düzeyde depresif belirtiler, 57

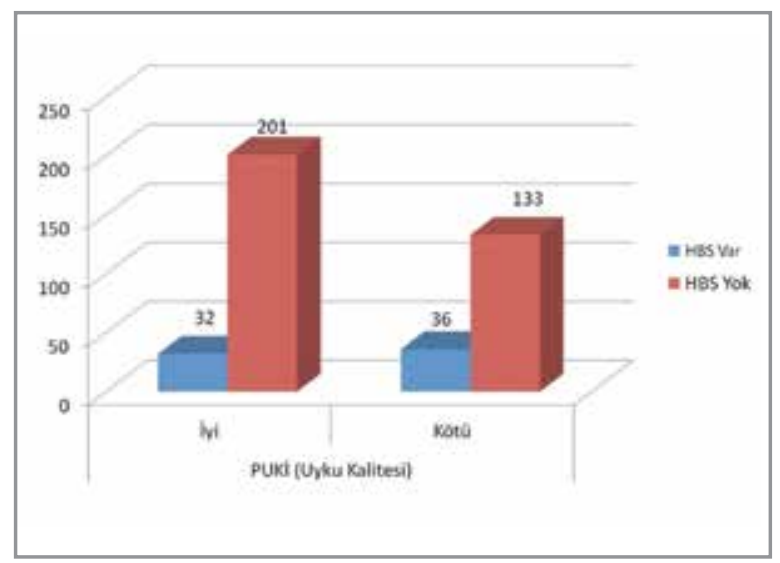

Şekil 1. Huzursuz bacak sendromu (HBS) tanısı konulan olguların pitsburg uyku kalitesi indeksi (PUKi)'yle iyi veya kötü uyku kalitesi durumları. 
(\%17.06) orta düzeyde depresif belirtiler, 10 (\%2.99) şiddetli düzeyde depresif belirtiler olduğu görüldü (Şekil 2). HBS bulguları var olan olgularda HBS şiddet değerlendirme ölçeği ile BDÖ puanları arasında istatistiksel anlamlı pozitif korelasyon olduğu saptandı $\mathrm{p}=0.002, \mathrm{r}=0.372$ ) (Şekil 3).

Olguların BAÖ toplam puanı ortalama $10.06 \pm$ $6.21^{\prime}$ di. (0-57 puan). HBS bulguları var olan 68 olgunun BAÖ şiddetine göre 11 (\%16.17)'inde minimal düzeyde anksiyotik belirtiler, 34 (\%50)'ünde orta düzeyde anksiyotik belirtiler, 16 (\%23.52)'sında orta düzeyde anksiyotik belirtiler, 7 (\%10.29)'sinde şiddetli düzeyde anksiyotik belirtiler olduğu görüldü (Şekil 4).

HBS şiddet ölçeği ile BAÖ puanları arasında anlamIı ve pozitif yönlü korelasyon saptandı $(p<0.001$, $r=0.506)$ (Şekil 5).

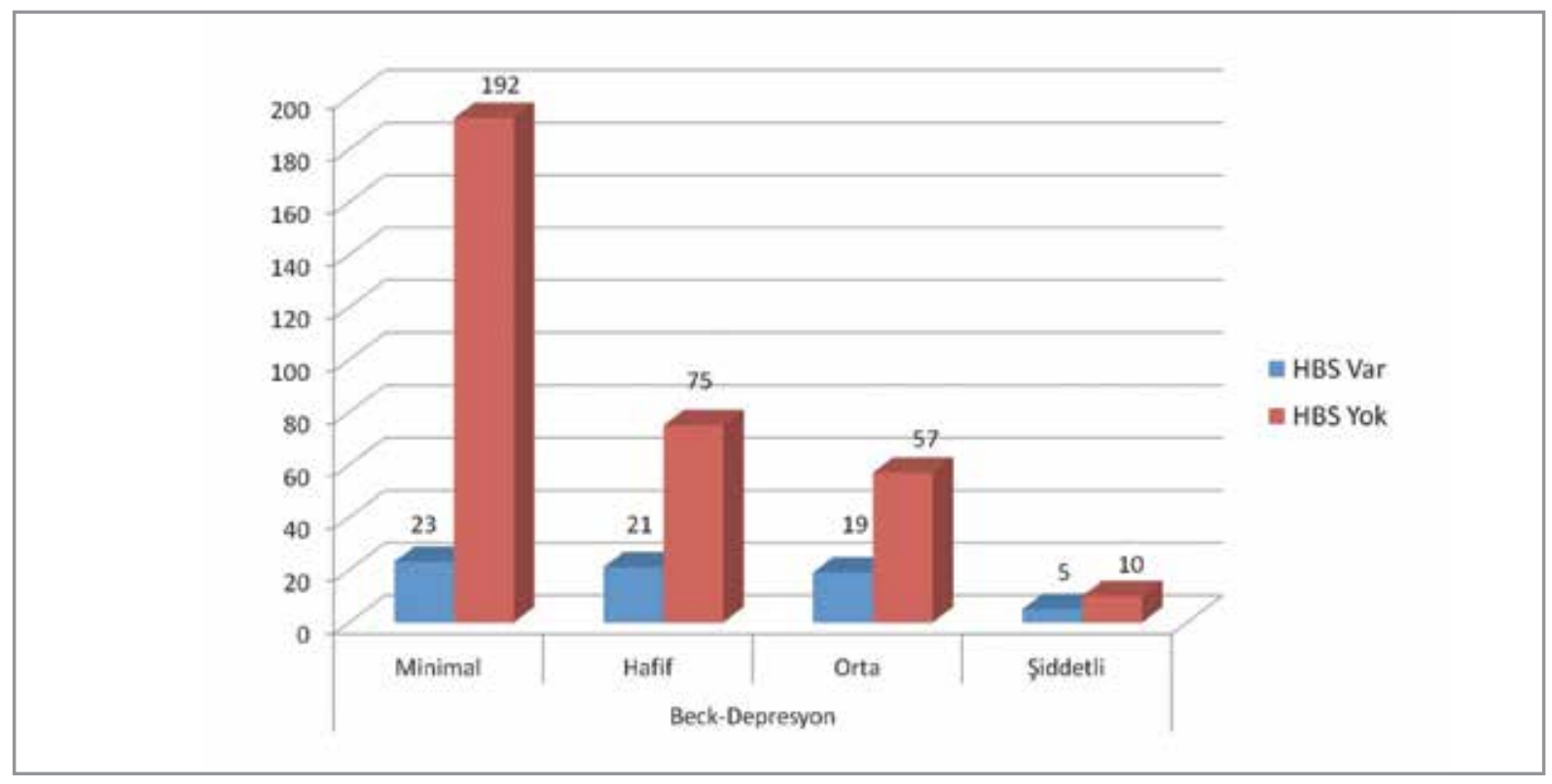

Şekil 2. Beck depresyon ölçeği (BDÖ)'yle değerlendirilen depresyon durumuna göre huzursuz bacak sendromu (HBS) tanısı konulan olguların dağılımı.

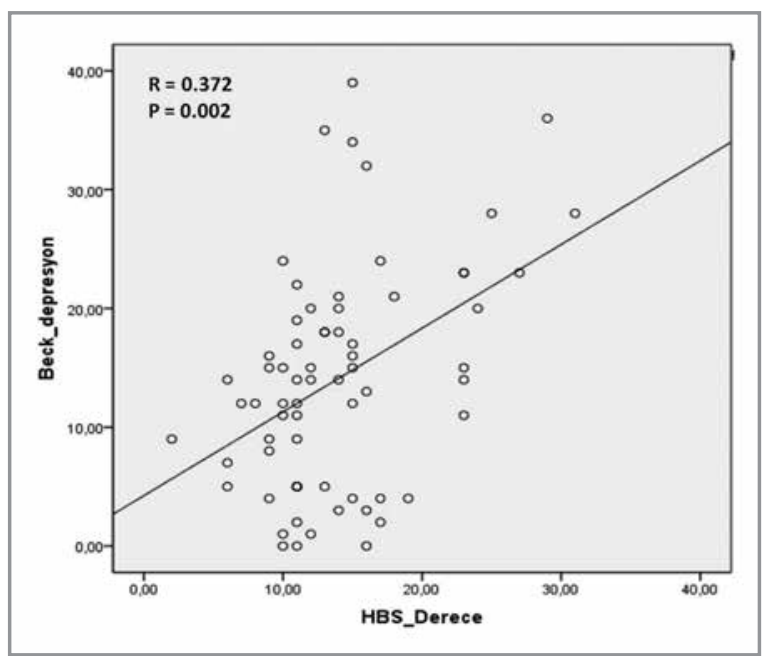

Şekil 3. Beck depresyon ölçeği (BDÖ)'yle değerlendirilen depresyon şiddeti ile huzursuz bacak sendromu (HBS) şiddetinin korelasyon eğrisi.

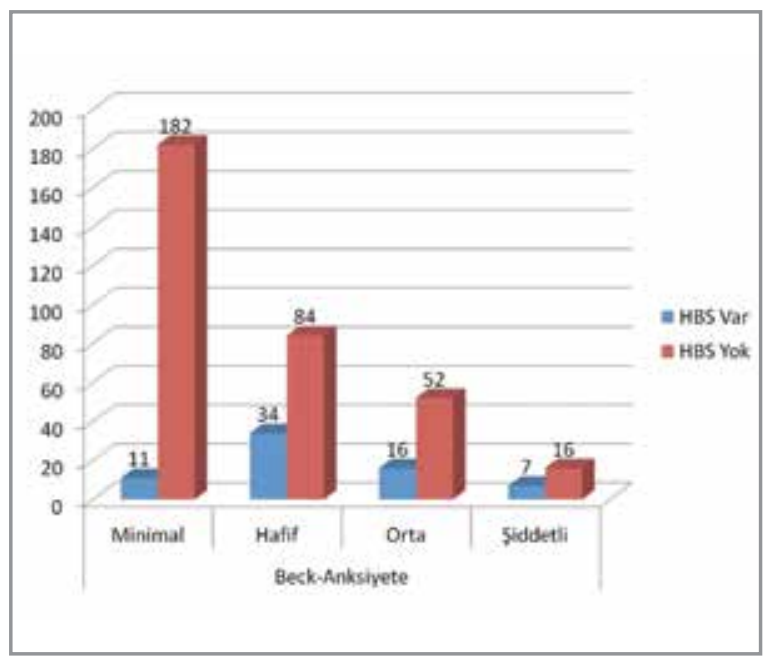

Şekil 4. Beck anksiyete ölçeği (BAÖ)'yle değerlendirilen anksiyete durumuna göre huzursuz bacak sendromu (HBS) tanısı konulan olguların dağııımı. 


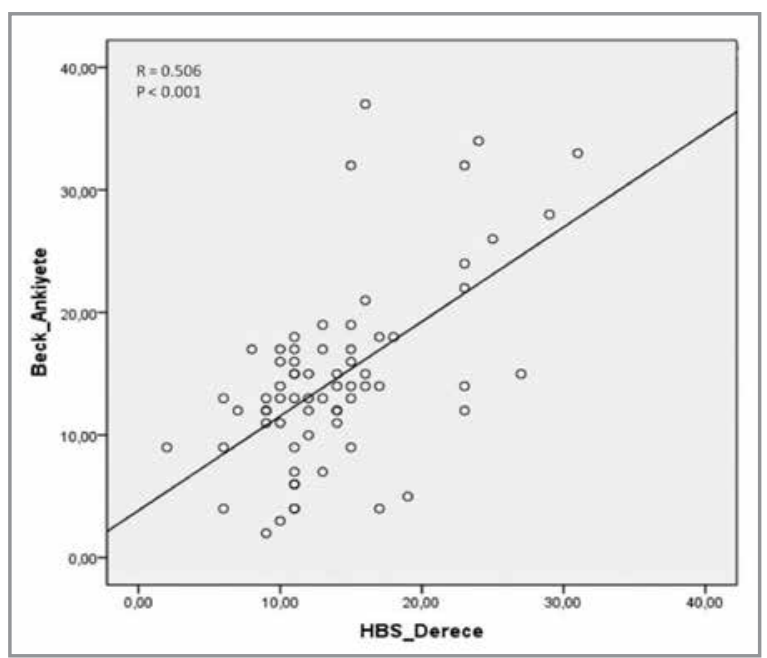

Şekil 5. Beck anksiyete ölçeği (BAÖ)'yle değerlendirilen anksiyete şiddeti ile huzursuz bacak sendromu (HBS) şiddetinin korelasyon eğrisi.

\section{TARTIŞMA}

HBS olguların çoğuna tanı konulamadığı için hastalığın görülme sıklığı kesin olarak bilinememektedir. Epidemiyolojik çalışmalara göre HBS toplumun \%1-15'inde görülmektedir (8). Özellikle Avrupa ve Kuzey Amerika'dan bildirilen raporlarda yaklaşık prevalans \% $10^{\prime}$ ken, Singapur, Japonya ve Hindistan gibi Asya ülkelerinde $\% 0.1$ gibi düşük oranlar da bildirilmektedir (9). Sadece Amerika Birleşik Devletleri $(\mathrm{ABD})$ 'nde 10 milyondan fazla yetişkin ve yaklaşık 1.5 milyon çocuk ve adölesan hastalıktan etkilenmektedir. Olguların 2/3'ü tıbbi yardıma ihtiyaç duymaktadır (10). HBS semptomları ile doktora başvuran hastaların çoğu orta ve ileri yaş hastalardan oluşmaktadır. Ancak olguların \%35-45'inde şikayetler 20 yaş öncesinde başlamaktadır (11). Ülkemizde üniversite örgencilerinde yapılan HBS sıklığı çalışmasında üniversite öğrencileri arasında HBS sıklığı \%18.4 olarak bulunmuştur (12). Bizim çalışmamızda da HBS sıklığı benzer şekilde bulunmuştur.

Uluslararası HBS Çalışma Grubu tarafından HBS tanı kriterleri 2014 yılında revize edilmiştir. 2014 yılında 4 olan tanı kriterleri 5'e çıkarılmıştır (2). Bizde bu araştırmada HBS yeni tanı kriterleri kullanılarak HBS sıklığının araştıııldığı Türkiye'den ilk çalışmayı sunduk. Çalışmamız HBS yeni tanı kriterleri kullanılarak, HBS tanısı almış olgularda uyku kalitesi, depresyon ve anksiyete ilişkisinin araştıııldığı literatürdeki ilk çalışmadır.

Patofizyolojik mekanizmaları halen açık olmasa da, kadın cinsiyet hastalık için bir risk faktörü olarak görünmektedir. Epidemiyolojik çalışmaların çoğunda kadınlarda yaklaşık 2 kat daha sık görüldüğü bildirilmiştir $(9,10)$. Çalışmamızda da literatürde bildirildiği gibi HBS'nin kız öğrencilerde görülme oranı daha yüksek olarak bulunmuştur.

Çalışmamızda sigara ve alkol kullanımıyla HBS görülme sıklığı arasında ilişki görülmemiştir. Literatürde sigara içenlerde HBS görülme sıklığının arttığını bildiren yayınlar olmakla birlikte, sigara ve alkol kullanımıyla HBS sıklığı arasında ilişkinin gösterilemediği bildirilmektedir $(13,14)$.

HBS özellikle geceleri ve immobilite periyotları sırasında bacaklarda huzursuzluk ve dizesteziyle karakterize bir sensori-motor bozukluktur (11). Bu hisler ve bacakları hareket ettirme ihtiyacı genelde uykuya dalma ve uykunun idamesini zorlaştırır. HBS'de uykuya dalma süresinin uzadığı, uyku kalitesinin ve uykunun idamesinin bozulduğu ve bunun HBS'ye bağlı sensorimotor duyular ve bacakları hareket ettirme dürtüsüne bağlı oluştuğu düşünülmektedir (15). Uyku kalitesinin PUKi ile değerlendirdiğimiz çalışmamızda HBS tanısı konan olgularda, HBS olmayan olgularla karşılaştırıldığında anlamlı derecede uyku kalitesinin bozulduğu saptandı. HBSŞDÖ ile PUKi puanları karşılaştırıldığında fark saptanmadı $(p=0.328)$.

Hipertansiyon ve diyabetle birlikte anksiyete, depresyon ve gastroözefageal reflü HBS ile birlikte en sık izlenen tıbbi komorbiditelerdir (16). Depresyonun HBS olan olgularda neredeyse 4 kat daha fazla görüldüğü, HBS'nin uyku bozuklukları ve yaşam kalitesinde azalmaya neden olarak depresif semptomlara yol açabileceği ifade edilmekle birlikte yorgunluk, konsantrasyon azalması gibi HBS semptomlarının da yanlış olarak depresif semptomlar olarak yorumlanabileceği de belirtilmektedir (17). HBS olan olgularda depresyon semptomlarının sık olmasının nedenini açıklayan birkaç neden vardır. Birincisi HBS çalışmamızda da gösterdiğimiz gibi kötü uyku kalitesine neden olmaktadır. Kötü uyku kalitesi yaşam kalitesini de etkilemektedir ve depresyon semptomlarının ortaya çıkmasına neden olmaktadır. İkincisi dopaminerjik sistemin hem HBS hem de depresyonun patogenezinde önemli rol oynadığı bilinmektedir (18).

Özellikle HBS tanılı hastalarda depresyon sıklığı \%10-50 arasında değişmektedir (19). Hornak ve arkadaşlarının yaptığı bir çalışmada HBS tanısı olan olgularda genel popülasyonla karşılaştırıldığında depresyon oranında artış olduğu bulunmuştur (20). 
Majör depresyon bozukluğu yaşam boyu prevalansı HBS olan hastalarında \%36.9'ken, sağlıklı kontrol grubunda \%15.2 olarak tespit edilmiştir [OR=2.9 (\%95 güven aralığı (GA) 1.5-4.4)]. Winklemann ve arkadaşları HBS ve depresyon arasında karmaşık bir ilişki olduğunu belirtmiştir (21). Li ve arkadaşları özellikle 56.399 depresyon bulgusu olmayan kadın hastanın 6 yıllık takibi sonucunda altta yatan HBS tanısı varlı̆ıında olmayanlara göre klinik olarak depresyona eğilimin daha sık ortaya çıktığını bildirmiştir (rölatif risk $(R R)=1.5,95 \%$ GA: 1.1-2.1; $p=0.02)(22)$. Hem HBS hem de depresyon hastaları arasında semptomların örtüşmesi nedeniyle tanı karmaşıklığına neden olmaktadır. HBS hastalarında görülen uyku bozuklukları, duygu durum rahatsızlıkları, ajitasyon ve konsantrasyonda azalma olması depresyonla karıştırılabilir. Özellikle HBS konusunda tecrübesi veya bilgisi olmayan klinisyenler tarafından eşlik eden depresyon semptomları nedeniyle bu hastalara yanlış tanılar konulabilmektedir (23). Çalışmamızda HBS olan olgular HBS olmayan olgularla karşılaştırıldığında BDÖ puanlarının daha yüksek olduğu bulunmuştur. HBS saptanan olgularda HBS şiddet değerlendirme ölçeğiyle BDÖ puanları arasında pozitif korelasyon bulunmuştur. Bu da HBS tanılı hastalarda HBS şiddeti arttıkça depresyon bulgularının da arttığını göstermektedir.

Anksiyete bozukluklarının genel popülasyonla karşılaştııılığında HBS hastalarında artmış olarak bulunmaktadır. Çalışmamızda da HBS olan olgular HBS olmayan olgularla karşılaştırıldığında BAÖ puanlarının daha yüksek olduğu bulunmuştur. Winkelmann ve arkadaşlarının yapmış oldukları bir çalışmada 130 HBS tanısı alan hastalarla 2265 genel toplumdan diğer hastalıkları olanlarla karşılaşııııldığında anksiyete bozukluklarının oranında artış olduğu görülmüştür [genel anksiyete bozukluğu $(\mathrm{OR}=3.5 ; \% 95 \mathrm{GA}=$ 1.7-7.1] (21). Çalışmamızda HBS saptanan olgularda HBS şiddet değerlendirme ölçeğiyle BAÖ puanları arasında da pozitif korelasyon olduğu saptanmıştır. HBS ve anksiyete bozuklukları arasındaki sebepsonuç ilişkisi muhtemelen karmaşık ve çift yönlüdür ve etyolojik mekanizmaları iyi anlaşılmış değildir. Her iki hastalıkta nörobiyolojik ve genetik nedenler etkili olabilir. HBS'nin diğer psikiyatrik bozukluklarda da olduğu gibi anksiyeteyi tetikleyici bir faktör olabileceği de düşünülmelidir. HBS'nin anksiyete bozukluklarının artmasına neden olabileceğini açıklayan birkaç mekanizma olabilir. HBS hastalarında görülen uyku bozuklukları anksiyeteye yatkınlığı artırabilir. HBS total uyku süresinde yetersizliğe neden olmaktadır. HBS'li hastalarda normal gönüllülerle karşılaşııııldığında uyku yoksunluk semptomlarının ve anksiyete durumlarının arttığı görülmüştür $(24,25)$. Roy-Byrne ve arkadaşları akut uyku yoksunluğunun panik atak hastaları için güçlü bir tetikleyici olduğunu göstermiş̧tir (26). Bu sonuçlardan yola çıkarak, hastalığın psikolojik belirtilerini tanımak ve bu belirtilerle mücadele etmenin önemli olacağını düşünmekteyiz.

HBS primer olabileceği gibi demir eksikliği anemisi varlığında da gelişebildiği bildirilmiştir. Demir eksikliğinde beyinde lokal dopamin düzeylerindeki azalmaya bağlanmaktadır $(27,28)$. Çalışmamız anket çalışması olması ve katılımcıların laboratuvar bilgilerinin bilinmemesi nedeniyle katılımcıların ne kadar bölümünde demir eksikliği anemisinin olduğu bilinmemektedir.

Çalışmamızın sonuçlarında tıp fakültesi öğrencilerinde HBS sıklığı literatürle karşılaştııılı̆̆ında yüksek olarak tespit edilmiştir. Klinik ve preklinik öğrencilerde HBS sıklığı benzer bulunmuştur. HBS tanısı konulan olgularda kötü uyku kalitesine sahip oldukları bulunmuştur. HBSŞDÖ'yle hesaplanan şiddetle anksiyete ve depresyon düzeyleri arasında pozitif korelasyon mevcuttur. Sonuç olarak, HBS bazı psikolojik duygu durum bozukluklarıyla birlikte olabilir. Tıp fakültesi gibi zor eğitim sürecinin öğrencilerde kötü uyku kalitesine, anksiyete ve depresyon gibi duygu durum bozukluklarına neden olmakta ve bunlara bağlı olarak HBS sıklığının da arttığı görülmektedir. HBS ve duygu durum bozukluklarının ortak semptomlarının olması nedeniyle, özellikle hekimlerde farkındalık oluşmasının HBS hastalığının erken teşhisinin konulmasında faydalı olacağı düşünülmektedir.

\section{KAYNAKLAR}

1. Ekbom KA. Restless legs: a clinical study. Acta Med Scand Suppl 1945;158:1-123.

2. Allen RP, Picchietti DL, Garcia-Borreguero D, Ondo WG, Walters AS, Winkelman JW, et al. International restless legs syndrome study group. Restless legs syndrome/WillisEkbom disease diagnostic criteria: updated international restless legs syndrome study group (IRLSSG) consensus criteria-history, rationale, description, and significance. Sleep Med 2014;15:860-73.

3. Ağargün MY, Kara H, Anlar Ö. PUKi. Pittzburg uyku kalitesi indeksinin geçerlilik ve güvenilirliği. Türk Psikiyatri Dergisi 1996;7:107-15. 
4. Beck AT. An inventory for measuring depression. Arch Gen Psychiatry 1961;4:561-71.

5. Ulusoy $M$, Şahin NH, Erkmen H. Turkish version of the beck anxiety inventory: psychometric properties. J Cogn Psychother 1998;12:163-72.

6. Hisli N. Beck Depresyon Envanteri'nin üniversite öğrencileri için geçerliği, güvenirliği. Psikoloji Dergisi 1989;6:3-13.

7. Beck AT, Epstein N, Brown G, Steer RA. An inventory for measuring clinical anxiety: psychometric properties. I Consult Clin Psychol 1988;56:893-7.

8. Chokroverty S. Editor's corner: restless leg syndrome, a common disease uncommonly diagnosed. Sleeep Med 2003;4:91-3.

9. Merlino G, Valente M, Serafini A, Gigli GL. Restless legs syndrome: diagnosis, epidemiology, classification and consequences. Neurol Sci 2007;28:37-46.

10. Hening W, Allen RP, Tenzer P, Winkelman WJ. Restless legs syndrome: demographics, presentation, and differential diagnosis. Geriatrics 2007;62:26-9.

11. Spiegelhalder K, Hornyak M. Restless legs syndrome in older adults. Clin Geriatr Med 2008;24:167-80.

12. Özcan TA, Meral H, Özcan H. Ordu Üniversitesi ögrencileri arasında huzursuz bacak sendromu sıklığı, özellikleri ve farkındalığı. Nöropsikiyatri Arşivi 2013;50:175-9.

13. Lavigne GL, Labbezoo F, Rompre PH, Nielsen TA, Montplaisir J. Cigarette smoking as a risk factor or an exacerbating factor for restless legs syndrome and sleep bruxism. Sleep 1997;20:290-3.

14. Hadjigeorgiou GM, Stefanidis I, Dardiotis E, Aggellakis K, Sakkas GK, Xiromerisiou G, et al. Low RLS prevalence and awareness in central Greece: an epidemiological survey. Eur J Neurol 2007;14:1275-80.

15. Karadeniz Kaynak D. Insomni yakınması ardında yatan uyku bozuklukları; huzursuz bacak sendromu ve uykuda periyodik hareket bozukluğu. Arch Neuropsychiatry 2007;44:95-100.

16. Phillips B, Hening $W$, Britz P, Mannino D. Prevalence and correlates of restless legs syndrome: results from the 2005 national sleep foundation poll. Chest 2006; 129:76-80.

17. Kim KW, Yoon IY, Chung S, Shin YK, Lee SB, Choi EA, et al. Prevalence, comorbidities and risk factors of restless legs syndrome in the Korean elderly population-results from the korean longitudinal study on health and aging. I Sleep Res 2010;19:87-92.
18. Allen RP. Controversies and challenges in defining the etiology and pathophysiology of restless legs syndrome. Am J Med 2007;120:S13-21.

19. Kim WH, Kim BS, Kim SK, Chang SM, Lee DW, Cho MJ, et al. Restless legs syndrome in older people: a communitybased study on its prevalence and association with major depressive disorder in older korean adults. Int I Geriatr Psychiatry 2012;27:565-72.

20. Hornyak M. Depressive disorders in restless legs syndrome: epidemiology, pathophysiology and management. CNS Drugs 2010;24:89-98.

21. Winkelmann J, Prager $M$, Lieb R, Pfister $H$, Spiegel $B$, Wittehen $H U$, et al. 'Anxietas tibiarum'. Depression and anxiety disorders in patients with restless legs syndrome. I Neurol 2005;252:67-71.

22. Li Y, Mirzaei F, O'Reilly EJ, Winkelman J, Malhotra A, Okereke Ol, et al. Prospective study of restless legs syndrome and risk of depression in women. Am J Epidemiol 2012;176:279-88.

23. Mackie S, Winkelman JW. Restless legs syndrome and psychiatric disorders. Sleep Med Clin 2015;10:351-7.

24. Klumpers UMH, Veltman DJ, van Tol MJ, Kloet $R W$, Boellaard R, Lammertsma AA, et al. Neurophysiological effects of sleep deprivation in healthy adults, a pilot study. PLOS ONE 2015;10: e0116906.

25. Baum KT, Desai A, Field J, Miller LE, Rausch J, Beebe DW. Sleep restriction worsens mood and emotion regulation in adolescents. J Child Psychol Psychiatry 2014;55:180-90.

26. Roy-Byrne PP, Uhde TW, Post RM. Effects of one night's sleep deprivation on mood and behavior in panic disorder Patients with panic disordercompared with depressed patients and normal controls. Arch Gen Psychiatry 1986;43:895-9.

27. Altunbaş Ateş E. Huzursuz bacaklar sendromu. Turkish Family Physician 2012;3:19-29.

28. Daubian-Nosé P, Frank MK, Esteves AM. Sleep disorders: A review of the interface between restless legs syndrome and iron metabolism. Sleep Sci 2014;7:234-7. 